\title{
Analisis Sentimen Pemilihan Presiden Indonesia Tahun 2019 Di Twitter Berdasarkan Geolocation Menggunakan Metode Naïve Bayesian Classification
}

\author{
Wiranto Horsen Silitonga ${ }^{1}$, Jay Idoan Sihotang*2 \\ ${ }^{1}$ PT. Bank OCBC NISP, Indonesia \\ ${ }^{2}$ Fakultas Teknologi Informasi, Universitas Advent Indonesia \\ e-mail: ${ }^{1}$ wirantohorsen@gmail.com, *2jay.sihotang@unai.edu
}

\begin{abstract}
Abstrak
Pemilihan Presiden Indonesia 2019 ramai diperbincangkan di dunia nyata maupun dunia maya, khususnya di media sosial Twitter. Semua orang bebas berpendapat tentang pasangan calon Presiden Indonesia 2019 tersebut. Sehingga memunculkan banyak opini, tidak hanya opini yang positif atau netral, ada pula opini negatif. Media sosial khususnya Twitter sekarang ini menjadi salah satu tempat promosi atau kampanye yang efektif dan efisien untuk menggait para pendukung. Dalam hal ini peneliti akan melakukan riset terhadap tokoh publik yang mencalonkan diri menjadi Presiden Indonesia. Metode penelitian yang digunakan dalam riset kali ini adalah algoritma klasifikasi Naïve Bayesian Classifer. Data yang digunakan adalah tweet berbahasa Indonesia dengan kata kunci Jokowi (\#Jokowi2Periode) dan Prabowo (\#PrabowoSandi) sebanyak 1009 data tweet selama 5 bulan dimulai dari 1 September 2019 sampai 31 Januar1 2019. Yang di mana data tweet tersebut diambil dari empat daerah terbesar di Indonesia, yaitu Jakarta, Bandung, Medan, dan Surabaya. Setiap data akan diambil secara manual menggunakan Geolocation API yang telah di sediakan oleh Twitter melalui Twitter search. Hasil dari klasifikasi menggunakan algoritma Naive Bayesian Classifier didapat 839 tweet positif, 32 tweet negatif, dan 67 tweet netral dari 938 tweet keseluruhan, atau dalam bentuk persentase ada $90 \%$ merupakan sentimen positif, 3\% sentimen negatif, dan 7\% sentimen netral terhadap bapak Joko Widodo. Dan 56 tweet positif, 6 tweet negatif, dan 8 tweet netral dari 70 tweet keseluruhan, atau dalam bentuk persentase ada $80 \%$ merupakan sentimen positif, $9 \%$ sentimen negatif, dan $11 \%$ sentimen netral terhadap bapak Prabowo. Tingkat akurasi yang dihasilkan dari algoritma Naïve Bayesian Classifier sendiri terhadap penelitian ini sebesar $77,62 \%$.
\end{abstract}

Kata Kunci: Analisa Sentimen, Pemilihan Presiden Indonesia, Jokowi, Prabowo, Geolocation, Datamining, Naïve Bayesian Classifier, Multinominal Naïve Bayes

\section{Sentiment Analysis of Indonesia Presidency Election 2019 on Twitter Based on Geolocation Using Naïve Bayesian Classification Method}

\begin{abstract}
2019 Indonesian Presidential Election is crowded to be discussed in the real world and also cyberspace, specifically on Twitter. Everyone is free to agree on the 2019 Indonesian Presidential candidate pair. Opinion raises many opinions, not only positive or neutral opinions but there are also negative opinions. Twitter's is now one of the most effective and efficient promotional or campaign venues to attract supporters. In this case, the researcher will conduct research on community leaders who are running for the presidency of Indonesia. The research method used in this study is the Naive Bayesian Classifier classification algorithm. The data used are Indonesian tweets with Jokowi (\# Jokowi2Periode) and Prabowo (\#PrabowoSandi) keywords totaling 1009 data tweets for 5 months starting from September 1, 2019 to 31 January 1, 2019. Indonesia, namely Jakarta, Bandung, Medan, and Surabaya. Each data will be taken manually by using the Geolocation API that has been provided by Twitter via a Twitter search. The results
\end{abstract}


of the classification using the Naive Bayesian Classifier algorithm received 839 positive tweets, 32 negative tweets, and 67 neutral tweets from 938 overall tweets, or in the form of a percentage, there were $90 \%$ containing positive sentimen, 3\% negative, and 7\% negative sentimen towards Mr. Joko Widodo. And 56 positive tweets, 6 negative tweets, and 8 neutral tweets from 70 overall tweets, or in the form of the percentage there are $80 \%$ positive sentimens, $9 \%$ negative sentimens, and $11 \%$ neutra/sentimens towards Mr. Prabowo. The level of accuracy generated from the Naive Bayesian Classifier algorithm itself for this study amounted to $77.62 \%$.

Keywords: Sentiment Analysis, Indonesia Presidency Election, Jokowi, Prabowo, Geolocation, Datamining, Naïve Bayesian Classifier, Multinominal Naïve Bayes

\section{Pendahuluan}

Sistem demokrasi adalah suatu sistem yang berlaku pada negara Indonesia. Hal tersebut dibuktikan dengan diadakannya pemilihan umum pada setiap ajang penentuan pemimpin yang baru. Baik itu presiden, wakil presiden, ataupun lembaga perwakilan rakyat. Pada setiap ajang pemilihan umum tersebut, setiap calon tokoh politik akan melihat atau mempertimbangkan popularitas mereka dari setiap opini masyarakat. Dikarenakan perkembangan zaman yang sudah begitu pesat hingga merambah sampai perkembangan teknologi komunikasi saat ini, mengubah kecenderungan masyarakat dalam mengekspresikan opininya pada sebuah jejaring sosial. Dan Twitter adalah salah satu jejaring sosial yang sangat popular di kalangan pengguna internet saat ini [1][2].

Dan isi pada Twitter sendiri yang disebut tweet berisikan tentang apa yang sedang dilakukan atau dirasakan, percakapan, berbagi informasi, dan pelaporan suatu berita. Pada umumnya sebuah tweet hanya untuk melakukan posting hal mengenai diri pengguna dan berbagi informasi. Isi tweet juga dapat mengekspresikan perasaan atau mood pengguna, hal ini bersifat penilaian subjektif atau opini. Opini melalui tweet inilah yang dapat dimanfaatkan peneliti untuk melakukan analisis sentimen masyarakat terhadap tokoh politik yang akan maju sebagai calon presiden Indonesia tahun 2019.

Dengan banyaknya tweet yang beredar di Twitter yang membahas mengenai Pemilihan Presidan, peneliti termotivasi untuk melihat Analisa sentimen dari tweet yang ada di Twitter. Analisis sentimen dan opinion mining adalah bidang studi yang menganalisis pendapat seseorang, sentimen seseorang, evaluasi seseorang, sikap seseorang dan emosi seseorang ke dalam bahasa tertulis. Teknik analisis sentimen dapat mendukung banyak keputusan dalam banyak skenario. Penelitian ini menggunakan tiga class attribute, yaitu positif, netral dan negatif, karena di internet komentar yang muncul dapat berupa komentar positif, netral dan negatif [3].

Data terhadap penelitian ini diperoleh melalui tweet search pada aplikasi Twitter dengan hashtag dan geolocation yang telah ditentukan. Sehingga diperolehlah sebuah dokumen baru yang digolongkan menjadi 3 bagian polaritas yaitu, positif, negatif, dan netral. Di mana hal ini dilakukan untuk diperolehnya data yang akurat. Kumpulan data yang sudah diperoleh akan melewati tahap PreProcessing. Hasil dari tahap PreProcessing tersebut akan diklasifikasikan dengan metode Naïve Bayes Classifier [4].

\section{Metode Penelitian}

\section{Pengumpulan Data}

Dataset yang akan digunakan dalam penelitian tweet bahasa Indonesia yang merupakan hasil pencarian berdasarkan geolocation empat daerah yaitu Jakarta, Bandung, Surabaya, dan Medan terhadap tagar tokoh politik yang akan maju sebagai calon presiden Indonesia 2019. Beberapa tagar yang diambil di antaranya, \#jokowizperiode(Joko Widodo) dan \#prabowosandi (Prabowo Subianto). Dataset didapatkan dengan cara manual memanfaatkan API dari Twitter Search kemudian disimpan dalam format Ms. Excel. Pengambilan data tweet dilakukan pada 1 September 2018 hingga 31 Januari 2019. 


\section{Implementasi}

Implementasi penelitian ini dilakukan dengan langkah kerja seperti Gambar.1.

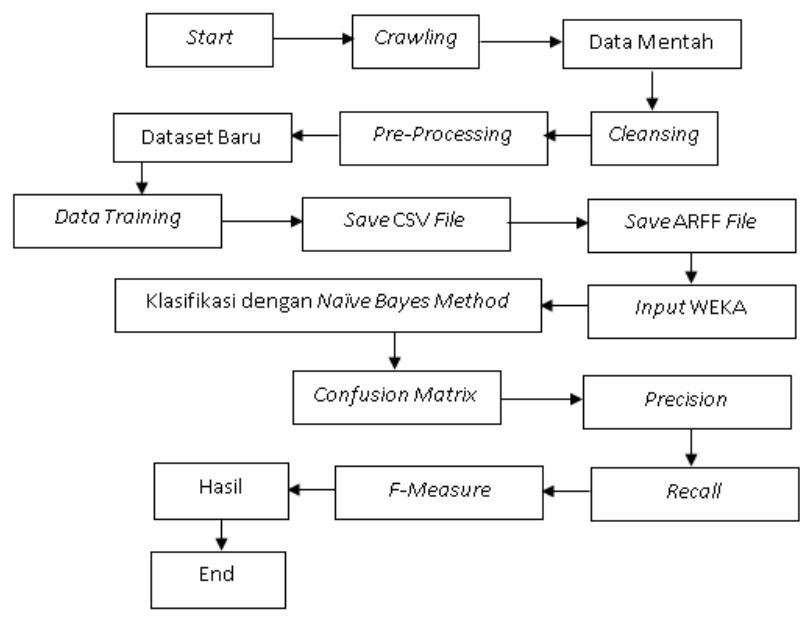

Gambar 1 Diagram Blok

Proses awal pada tahapan implementasi adalah pengumpulan dataset yang akan digunakan baik untuk testing maupun training. Pengumpulan dataset dengan cara memanfaatkan API dari pihak Twitter melalui teknik crawling. Hasil dari crawling data kemudian disimpan ke dalam Excel. Kemudian dilakukan cleansing dan preprocessing data untuk menjadikan sederhana dimensi dari dataset. Hasil dari tweet yang sudah diproses dan masuk kategori opini akan dipisahkan menjadi 3 kategori sentimen. Yaitu sentimen yang mempunyai polaritas positif, negatif dan netral. Hasil tweet yang dipisahkan tadi nantinya akan digunakan sebagai dataset training di mana proses pemisahannya dilakukan secara manual. Selanjutnya dataset tersebut disimpan dalam bentuk file CSV dan ARFF dan di input pada WEKA. Setelah seluruh proses dilakukan, barulah klasifikasi tweet menggunakan metode Naive Bayes Classifier dimulai.

\section{Preprocessing Data}

Sebelum dataset tweet siap digunakan maka akan terlebih dahulu dilakukan pre-processing data sehingga dataset telah bersih dan siap digunakan dalam proses selanjutnya. Pada tahap pre-processing data, dilakukan tahap text mining yang di mana melewati 9 tahap penambangan teks. Yaitu proses ekstraksi pola pada sebuah kalimat, yang di mana akan menghasilkan kalimat yang benar. Berikut adalah 9 tahap penambangan teks yang akan dilakukan [5].

1. Normalisasi Fitur.

Dalam proses Normalisasi Fitur peneliti akan membuang komponen yang biasa terdapat pada sebuah tweet yaitu, username, URL, RT (tanda retweet), dan Hashtag.

2. Tokenizer

Dalam proses Tokenizer peneliti akan memisahkan sebuah kalimat menjadi per kata atau word.

3. Case-Folding

Dalam proses Case-Folding peneliti akan mengubah semua huruf besar menjadi huruf kecil atau lowercase.

4. Clean Number

Dalam proses Clean Number peneliti akan menghapus setiap angka yang berada di depan atau di akhir sebuah kata.

5. Convert Word

Dalam proses Convert Word peneliti akan menyempurnakan sebuah kata yang tidak baku menjadi kata baku.

6. Convert Number

Dalam proses Convert Number peneliti akan menyempurnakan sebuah kata di mana memiliki angka di pertengahan kata yang dijadikan sebuah karakter huruf yang sebenarnya. 
7. Filtering

Dalam proses Filtering peneliti akan menghapus seluruh stop-word (yang, dan, di, dari, dll.) yang terdapat dalam kalimat.

8. Phrase Detection

Tahap ini bertujuan untuk menemukan 2 kata atau lebih yang merupakan frasa kata.

9. Stemming

Pada proses stemming terhadap contoh kalimat yang ditentukan terdapat tiga kata yang memiliki kata dasar.

\section{Penentuan Class Attribute}

Setelah melakukan preprocessing pada data tweet selanjutnya adalah menentukan class attribute. Tujuan dari class attribute adalah memberikan parameter kepada masyarakat terhadap objek tertentu secara akurat. Class attribute digunakan dalam penelitian ini ada 3 aspek, yaitu: Sentimen Positif, Sentimen Netral, dan Sentimen Negatif [3]. Hasil penentuan Class Attribute dapat dilihat pada Tabel 1.

Tabel 1 Pemberian Class Attribute Positif, Negatif, dan Netral

\begin{tabular}{|c|c|c|}
\hline No. & Tweet & Sentimen \\
\hline 1 & desa maju sejak pemerintah jokowi angka nganggur turun & Netral \\
\hline 2 & semoga sehat bapak presiden abdi untuk negara & Positif \\
\hline 3 & $\begin{array}{l}\text { presiden jokowi resmi bangkit listrik tenaga mesin gas arun daya listrik } \\
\text { seratus delapan puluh empat mega watt untuk butuh warga lhokseumawe }\end{array}$ & Netral \\
\hline 4 & mantap sekali semoga pak jokowi kenan terima & Positif \\
\hline 5 & apa menurutmu terlihat baik & Positif \\
\hline 6 & $\begin{array}{l}\text { prabowo tampil percaya diri sebagai bicara utama acara the world in two } \\
\text { thousand and nineteen gala dinner singapura dua puluh tujuh bulan } \\
\text { sebelas dua ribu delapan belas }\end{array}$ & Positif \\
\hline 7 & $\begin{array}{l}\text { maaf pak prabowo sandiaga uno saya bisa transfer segini ya pak percaya } \\
\text { saya terus juang doa untuk menang bapak }\end{array}$ & Netral \\
\hline 8 & segar adek baju biru lupa pilih presiden baru nomor dua & Netral \\
\hline 9 & empek empek kau berdebat urus negara & Negatif \\
\hline 10 & biarkan prabowo sandiuno juang sendiri rapat baris indonesia adil makmur & Positif \\
\hline
\end{tabular}

\section{Proses Training Metode Naive Bayes Menggunakan WEKA}

Proses training ialah proses pengujian data yang telah ditentukan Class Attributenya secara manual sebagai kamus data dalam penentuan proses testing terhadap sentimen dengan nilai conditional probabilities [6]. Sehingga diperoleh hasil sentimen yang lebih akurat baik itu positif, negatif, dan netral. Dalam penelitian ini diambil 10 tweet yang dijadikann sebagai object data training. Persamaan Naïve Bayes yang dipakai terhadap proses training pada WEKA ialah persamaan Multinomial Naïve Bayes. Ada pun persamaannya sebagai berikut

$$
\mathrm{P}(\mathrm{c} \mid \mathrm{d}) \propto \mathrm{P}(\mathrm{c}) \prod_{1 \leq k \leq n d} \mathrm{P}(\mathrm{tk} \mid \mathrm{c})
$$

Keterangan:

$\mathrm{P}(\mathrm{tk} \mid \mathrm{c})$ : conditional probabilities dari kata $\mathrm{t}_{\mathrm{k}}$.

$\mathrm{P}(\mathrm{c}) \quad$ : prior probabilities dari dokumen kelas $\mathrm{c}$.

Untuk memperoleh nilai dari pada prior probabilities dinyatakan dalam persamaan :

$$
\mathrm{P}(\mathrm{c})=\frac{\mathrm{Nc}}{\mathrm{N}}
$$

Keterangan:

$\mathrm{N}_{\mathrm{c}} \quad$ : Jumlah dokumen training dalam kelas $\mathrm{C}$.

$\mathrm{N} \quad$ : Jumlah keseluruhan dokumen training dari seluruh kata.

Dan untuk persamaan dari pada conditional probabilities ialah: 


$$
\mathrm{P}(\mathrm{t} \mid \mathrm{c})=\frac{T c \mathrm{t}}{\sum \mathrm{t}^{\prime} \in V T c t}
$$

Keterangan :

$\mathrm{T}_{\mathrm{ct}} \quad=$ Jumlah kemunculan kata $\mathrm{t}$ dalam sebuah dokumen training pada kelas $\mathrm{c}$.

$\frac{\mathrm{Tct}}{\Sigma \mathrm{t} \in \text { VVTCt }}=$ Jumlah total keseluruhan kata dalam dokumen training pada kelas $\mathrm{c}$.

$\mathrm{t}^{\prime} \quad=$ Jumlah total kata dalam dokumen training.

Untuk menghilangkan nilai nol pada sebuah dokumen, digunakannya laplace smoothing sebagai proses penambahan nilai 1 pada setiap nilai $T_{c t}$ pada perhitungan conditional probabilities dan dinyatakan dalam persamaan:

$$
\mathrm{P}(\mathrm{tPtk} \mid \mathrm{c})=\frac{\mathrm{Tct}+1}{\sum \mathrm{t}^{\prime} \in V t c t+B^{\prime}}
$$

$\mathrm{B}^{\prime}=$ Total kata unik pada keseluruhan kelas dalam dokumen training.

Untuk memperoleh nilai probabilitas yang tinggi setiap kata digunakan laplace smoothing atau addone, laplace smoothing digunakan agar nilai dari probabilitas masing-masing kata dapat memenuhi syarat yaitu tidak sama dengan 0 . Jika nilai dari probabilitas kata adalah 0 maka data training maupun testing tidak akan pernah cukup untuk mewakili frekuensi saat terdapat kejadian langkah.

Tabel 2 Contoh Data Training

\begin{tabular}{|c|l|c|}
\hline No. & \multicolumn{1}{|c|}{ Tweet } & Sentimen \\
\hline 1 & desa maju sejak pemerintah jokowi angka nganggur turun & Positif \\
\hline 2 & semoga sehat bapak presiden abdi untuk negara & Positif \\
\hline 3 & $\begin{array}{l}\text { presiden jokowi resmi bangkit listrik tenaga mesin gas arun } \\
\text { daya listrik seratus delapan puluh empat mega watt untuk butuh } \\
\text { warga Ihokseumawe }\end{array}$ & Positif \\
\hline 4 & mantap sekali semoga pak jokowi kenan terima & Positif \\
\hline 5 & apa menurutmu terlihat baik & $\begin{array}{l}\text { Positif } \\
\text { world in two thousand and nineteen gala dinner singapura dua } \\
\text { puluh tujuh bulan sebelas dua ribu delapan belas }\end{array}$ \\
\hline 7 & $\begin{array}{l}\text { maaf pak prabowo sandiaga uno saya bisa transfer segini ya } \\
\text { pak percaya saya terus juang doa untuk menang bapak }\end{array}$ & Netral \\
\hline 8 & segar adek baju biru lupa pilih presiden baru nomor dua & Netral \\
\hline 9 & empek empek kau berdebat urus negara & Negatif \\
\hline
\end{tabular}

Tabel 3 Hasil Perhitungan Prior probabilities Class Attribute Untuk Setiap Kelas

\begin{tabular}{|c|c|}
\hline Atribut Kelas & P(class) \\
\hline Positif & $5 / 9$ \\
\hline Negatif & $1 / 9$ \\
\hline Netral & $3 / 9$ \\
\hline
\end{tabular}

Tabel 4 Hasil Perhitungan Prior probabilities Term Untuk Setiap Kelas

\begin{tabular}{|c|c|c|c|}
\hline Term & Positif & Negatif & Netral \\
\hline Desa & $1 / 53$ & $0 / 5$ & $0 / 50$ \\
\hline Sejak & $1 / 53$ & $0 / 5$ & $0 / 50$ \\
\hline Maju & $1 / 53$ & $0 / 5$ & $0 / 50$ \\
\hline Pemerintah & $1 / 53$ & $0 / 5$ & $0 / 50$ \\
\hline Angka & $1 / 53$ & $0 / 5$ & 050 \\
\hline Nganggur & $1 / 53$ & $0 / 5$ & $0 / 50$ \\
\hline Turun & $1 / 53$ & $0 / 5$ & $0 / 50$ \\
\hline Mantap & $1 / 53$ & $0 / 5$ & $0 / 50$ \\
\hline Terima & $1 / 53$ & $0 / 5$ & $0 / 50$ \\
\hline Sehat & $1 / 53$ & $0 / 5$ & $0 / 50$ \\
\hline Baik & $1 / 53$ & $0 / 5$ & $0 / 50$ \\
\hline Tampil & $1 / 53$ & $0 / 5$ & $0 / 50$ \\
\hline Percaya & $1 / 53$ & $0 / 5$ & $1 / 50$ \\
\hline Utama & $1 / 53$ & $0 / 5$ & $0 / 50$ \\
\hline
\end{tabular}




\begin{tabular}{|c|c|c|c|}
\hline Maaf & $0 / 53$ & $0 / 5$ & $1 / 50$ \\
\hline Menang & $0 / 53$ & $0 / 5$ & $1 / 50$ \\
\hline Doa & $0 / 53$ & $0 / 5$ & $1 / 50$ \\
\hline Untuk & $0 / 53$ & $0 / 5$ & $1 / 50$ \\
\hline Warga & $0 / 53$ & $0 / 5$ & $1 / 50$ \\
\hline Berdebat & $0 / 53$ & $1 / 5$ & $0 / 50$ \\
\hline Negara & $1 / 53$ & $1 / 5$ & $0 / 50$ \\
\hline
\end{tabular}

Tabel 5 Hasil Perhitungan Prior probabilities Term Untuk Setiap Kelas Dalam Bentuk Desimal

\begin{tabular}{|c|c|c|c|}
\hline Term & Positif & Negatif & Netral \\
\hline Desa & 0.01242 & 0.00884 & 0.00632 \\
\hline Sejak & 0.01242 & 0.00884 & 0.00632 \\
\hline Maju & 0.01242 & 0.00884 & 0.00632 \\
\hline Pemerintah & 0.01242 & 0.00884 & 0.00632 \\
\hline Angka & 0.01242 & 0.00884 & 0.00632 \\
\hline Nganggur & 0.01242 & 0.00884 & 0.00632 \\
\hline Turun & 0.01242 & 0.00884 & 0.00632 \\
\hline Mantap & 0.01242 & 0.00884 & 0.00632 \\
\hline Terima & 0.01242 & 0.00884 & 0.00632 \\
\hline Sehat & 0.01242 & 0.00884 & 0.00632 \\
\hline Baik & 0.01242 & 0.00884 & 0.00632 \\
\hline Tampil & 0.01242 & 0.00884 & 0.00632 \\
\hline Percaya & 0.01242 & 0.00884 & 0.01265 \\
\hline Utama & 0.01242 & 0.00884 & 0.00632 \\
\hline Maaf & 0.00621 & 0.00884 & 0.01265 \\
\hline Menang & 0.00621 & 0.00884 & 0.01265 \\
\hline Doa & 0.00621 & 0.00884 & 0.01265 \\
\hline Untuk & 0.00621 & 0.00884 & 0.01265 \\
\hline Warga & 0.00621 & 0.00884 & 0.01265 \\
\hline Berdebat & 0.00621 & 0.01769 & 0.00632 \\
\hline Negara & 0.01242 & 0.01769 & 0.00632 \\
\hline
\end{tabular}

\section{Proses Testing Metode Naive Bayes Menggunakan WEKA}

Alur pada proses testing kurang lebih sama dengan alur training. Hanya yang membedakan ialah pada saat proses testing selesai akan dihitung nilai probabilitas akhir. Data testing terdapat pada Tabel 6.

Tabel 6 Data Testing

\begin{tabular}{|c|l|c|}
\hline No. & \multicolumn{1}{|c|}{ Tweet } & Sentimen \\
\hline 0 & $\begin{array}{l}\text { biarkan prabowo sandiuno juang sendiri rapat baris indonesia adil } \\
\text { makmur }\end{array}$ & ? \\
\hline
\end{tabular}

Perhitungan probabilitas dihitung terlebih dahulu untuk memudahkan kalkulasi selanjutnya. Untuk hasilnya terdapat pada Tabel 7. Pada sebuah term yang kemunculannya lebih dari satu kali, nilai kemunculan tersebut menjadi pangkat dari nilai conditional probabilities-nya pada Tabel 7. dengan term frequency (tf) masing-masing. Kemudian jumlahkan nilainya terhadap masing-masing kelas.

\begin{tabular}{|c|c|c|c|c|}
\multicolumn{7}{|c|}{ Tabel 7 Hasil Nilai Conditional probabilities } \\
\hline Term & Tf & Positif & Negatif & Netral \\
\hline Biarkan & 1 & 0.00621 & 0.00884 & 0.00632 \\
\hline Juang & 2 & 0.00621 & 0.00884 & 0.01265 \\
\hline Sendiri & 1 & 0.00621 & 0.00884 & 0.00632 \\
\hline Rapat & 1 & 0.00621 & 0.00884 & 0.00632 \\
\hline Baris & 1 & 0.00621 & 0.00884 & 0.00632 \\
\hline Indonesia & 1 & 0.00621 & 0.00884 & 0.00632 \\
\hline Adil & 1 & 0.00621 & 0.00884 & 0.00632 \\
\hline Makmur & 1 & 0.00621 & 0.00884 & 0.00632 \\
\hline
\end{tabular}

Misalnya term "juang" memiliki kemunculan sebanyak 2 kali. Kemudian setiap probabilitas dari setiap kelas akan dipangkatkan dengan 2. Untuk nilai kemunculan yang sama agar proses kalkulasi tidak 
membebani maka proses tersebut dilakukan satu kali. Hal ini mempercepat proses pencarian probabilitas. Pada Tabel 8 merupakan hasil seluruh pemangkatan term yang ditemukan.

Tabel 8. Hasil Perkalian Nilai Conditionl Probabilities Dengan Term Frequency-nya

\begin{tabular}{|c|c|c|c|}
\hline Term & Positif & Negatif & Netral \\
\hline Biarkan & 0.00621 & 0.00884 & 0.00632 \\
\hline Juang & 0.00003 & 0.00007 & 0.00016 \\
\hline Sendiri & 0.00621 & 0.00884 & 0.00632 \\
\hline Rapat & 0.00621 & 0.00884 & 0.00632 \\
\hline Baris & 0.00621 & 0.00884 & 0.00632 \\
\hline Indonesia & 0.00621 & 0.00884 & 0.00632 \\
\hline Adil & 0.00621 & 0.00884 & 0.00632 \\
\hline Makmur & 0.00621 & 0.00884 & 0.00632 \\
\hline Total & 0.0435 & 0.06195 & 0.0444 \\
\hline
\end{tabular}

Pada Tabel 8 didapatkan nilai probabilitas setiap term. Untuk mendapatkan kelas yang diinginkan dari dokumen adalah dengan mengalikan probabilitas dokumen dengan probabilitas kelas yang didapat dari hasil perhitungan. Kemudian diambil nilai paling besar di antara ketiga kelas tersebut [7]. Sebagai contoh tweet ke 10. Didapatkan nilai probabilitas dari tweet 10 terhadap seluruh sentimen dengan cara mengalikan nilai prior probabilities dengan total nilai conditional probabilities untuk masing-masing kelas.

Probabilities tweet 10 pada sentimen positif :

$$
\mathrm{P}(\text { positif } \mid \text { tweet } 10)=\frac{5}{9} \times 0.0435=0.02416
$$

Probabilities tweet 10 pada sentimen negatif :

$$
\mathrm{P}(\text { negatif } \mid \text { tweet } 10)=\frac{1}{9} \times 0.0435=0.00483
$$

Probabilities tweet 10 pada sentimen netral :

$$
\mathrm{P}(\text { netral } \mid \text { tweet } 10)=\frac{3}{9} \times 0.0435=0.0145
$$

Dari hasil perhitungan probabilitas di atas diketahui probabilities tweet 10 terdapat pada sentimen positif karena memiliki nilai yang paling besar. Oleh sebab itu tweet 10 terklasifikasi pada sentimen positif.

\section{Performing Measure}

Langkah yang terakhir dari penelitian ini merupakan proses analisis dari sistem yang kita buat untuk mengukur akurasi dari sistem yang kita rancang sendiri. Pada tugas akhir kali ini proses pengukuran performansi diukur dari Precission, Recall,F-Measure dan Akurasi.

\section{Confusion Matrix}

Merupakan salah satu metode yang dapat digunakan untuk mengukur kinerja suatu metode klasifikasi pada dasarnya confusion matrix itu sendiri mengandung informasi yang membandingkan hasil klasifikasi yang dilakukan oleh sistem dengan hasil klasifikasi yang seharusnya. Tabel 9 adalah Confusion Matrix dari hasil klasifikasi Naive Bayes yang sudah terklasifikasi.

Tabel 9 Confusion Matrix.

\begin{tabular}{|c|c|c|c|c|}
\hline \multicolumn{2}{|c|}{} & \multicolumn{3}{c|}{ Predicted } \\
\cline { 3 - 5 } \multicolumn{2}{|c|}{ Actual } & Positif & Negatif & Netral \\
\hline & Positif & TP & FP & FP \\
\hline & Negatif & FN & TN & FN \\
\hline & Netral & FNe & FNe & TNe \\
\hline
\end{tabular}




\section{Precision}

Precision adalah jumlah data yang benar diklasifikasikan dengan sebuah kelas dibagi dengan jumlah total data yang telah diklasifikasikan ke dalam kelas tersebut dengan rumus sebagai berikut. Nilai precision digunakan untuk mengukur ketepatan rekomendasi yang dihasilkan oleh sistem.

$$
\text { Precision }=\frac{T P}{(T P+F P)}
$$

Di mana:

TP adalah True Positive, yaitu jumlah data positif yang terklasifikasi dengan benar oleh sistem FP adalah False Positive, yaitu jumlah data positif namun terklasifikasi salah oleh sistem

3. Recall

Recall adalah jumlah data yang benar diklasifikasikan dalam sebuah kelas dibagi dengan jumlah total data dalam kelas tersebut.

$$
\text { Recall }=\frac{T P}{(T P+F N)}
$$

Di mana:

TP adalah True Positive, yaitu jumlah data positif yang terklasifikasi dengan benar oleh sistem.

FN adalah False Negative, yaitu jumlah data negatif namun terklasifikasi salah oleh sistem.

4. F-Measure

F-Measure digunakan untuk mengevaluasi rata-rata nilai Precision dan Recal/ hasil klasifikasi.

$$
F-\text { Measure }=2 \times \frac{\text { Precision } x \text { Recall }}{\text { Precision }+ \text { Recall }}
$$

Di mana perhitungannya adalah 2 dikali dengan Precision dikali dengan hasil Recall dibagi jumlah Precision ditambah Recall

5. Akurasi

Akurasi merupakan parameter evaluasi terhadap sistem yang dibangun dalam penelitian tugas akhir ini. Berikut adalah rumus akurasi.

Di mana:

$$
\text { Akurasi }=T P+T N /(T P+F P+T N+F N)
$$

TP adalah True Positive, yaitu jumlah data positif yang terklasifikasi dengan benar oleh sistem.

TN adalah True Negative, yaitu jumlah data negatif yang terklasifikasi dengan benar oleh sistem.

FN adalah False Negative, yaitu jumlah data negatif namun terklasifikasi salah oleh sistem.

FP adalah False Positive, yaitu jumlah data positif namun terklasifikasi salah oleh sistem

\section{Hasil}

Setelah melakukan beberapa penelitian untuk menganalisa tweet menggunakan algoritma Naïve Bayesian Classifer, maka didapatkan hasil Analisa sebagai berikut:

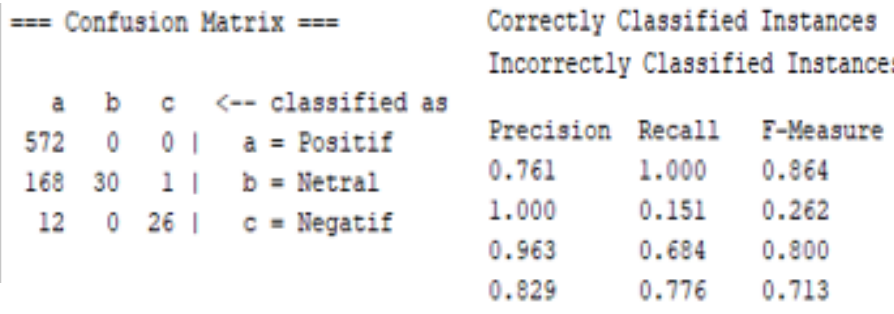

Gambar 2 Detail Klasifikasi Naive Bayesian Classification

Pada Gambar 2 dapat dianalisa bahwa Correctly Classified Instances merupakan suatu parameter dari tingkat akurasi yang benar $(77,62 \%=628$ data tweet $)$ dan tingkat dari kesalahan atau disebut dengan Incorrectly Classified Instances (22,37\% = 181 data tweet) yang bisa kita analisa dengan: 
Jumlah status yang diklasifikasi benar dan memang benar

$$
\begin{aligned}
& \text { Jumlah status (tweet) secara keseluruhan } \\
& \frac{628 \text { tweet }}{809 \text { tweet }} \times 100 \%=0.7762=77,62 \%
\end{aligned}
$$

Sedangkan untuk Incorrectly Classified Instances berikut dengan perhitungannya

$$
\begin{gathered}
\frac{\text { Jumlah status yang diklasifikasi salah dan memang salah }}{\text { Jumlah status (tweet) secara keseluruhan }} \times 100 \% \\
\frac{181}{809} \times 100 \%=0.2237=22.37 \%
\end{gathered}
$$

Penjelasan Confusion Matrix:

1. Baris pertama " 572 - 0 - 0" ada 572 tweet yang diprediksi sebagai sentimen positif dan memang benar merupakan sentimen positif.

2. Baris kedua "168 - 30 - 1" ada 199 tweet yang diprediksi seluruhnya sebagai sentimen netral tetapi 129 tweet di antaranya terklasifikasi sebagai sentimen positif, 30 tweet merupakan sentimen yang benar netral, dan 1 terklasifikasi sebagai sentimen negatif.

3. Baris ketiga "12 - $0-26$ " ada 38 tweet yang diprediksi sebagai sentimen negatif tetapi 12 tweet di antaranya terklasifikasi sebagai sentimen positif dan 26 di antaranya memang benar merupakan sentimen negatif.

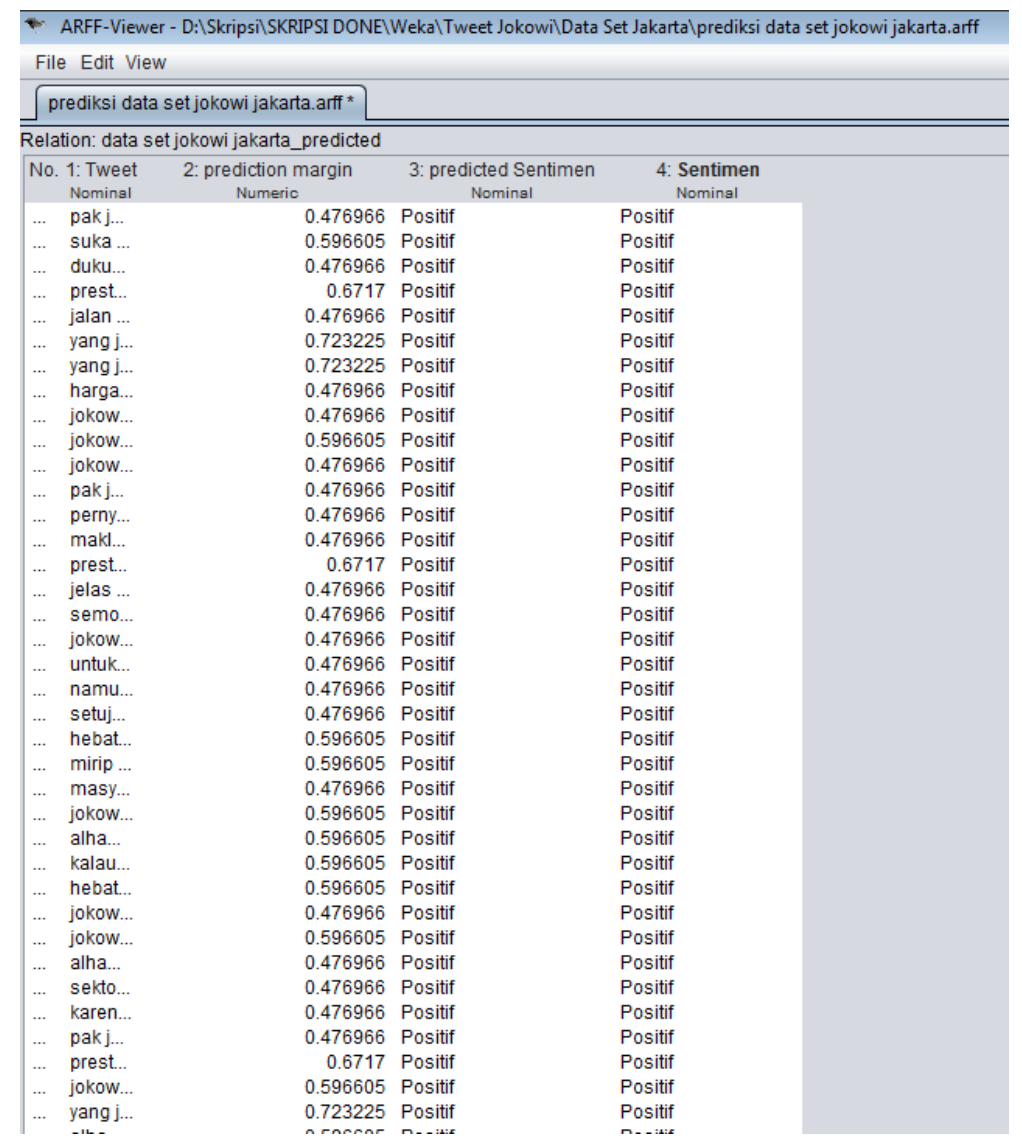

Gambar 3 Detail Nilai Conditional probabilities Klasifikasi Naive Bayesian Classification 
Maka jumlah data precision, recall, f-masure, akurasi tweet terhadap Bapak Joko Widodo adalah:

1. Precision

$$
\text { Precision }=\frac{572}{(572+168+12)}=0,76
$$

2. Recall

3. F-Measure

$$
\text { Recall }=\frac{572}{(572+0+0)}=1,00
$$

4. Akurasi

$$
\text { F-Measure }=2 \times \frac{1 \times 0,76}{1+0,76}=0.86
$$

$$
\text { Akurasi }=\frac{628}{808}=0,77
$$

Dan persentase jumlah data sentimen tweet terhadap Bapak Joko Widodo adalah sebagai berikut:

$$
\text { Hasil Prediksi }=\frac{\text { Jumlah tweet (sentimen) }}{\text { Jumlah keseluruhan tweet }} \times 100 \%
$$

A. Sentimen Positif terhadap Bapak Joko Widodo.

$$
\text { Hasil }=\frac{753}{809} \times 100 \%=0.9307=93 \%
$$

B. Sentimen Netral terhadap Bapak Joko Widodo.

$$
\text { Hasil }=\frac{30}{809} \times 100 \%=0.0370=4 \%
$$

C. Sentimen Negatif terhadap Bapak Joko Widodo.

$$
\text { Hasil }=\frac{27}{809} \times 100 \%=0.0321=3 \%
$$

Berdasarkan data yang diperoleh pada setiap geolocation yang ditentukan pada Tabel 11 dan 22 dari pada hashtag \#jokowi2periode dan \#prabowosandi diperoleh hasil persentase diagram terhadap dua tokoh tersebut.

Tabel 11. Jumlah Tweet Mengenai \#jokowi2periode Dari Jakarta, Bandung, Surabaya, dan Medan

\begin{tabular}{|c|c|c|c|c|c|}
\hline Kota & Jakarta & Bandung & Surabaya & Medan & Total \\
\hline Tweet & 809 & 62 & 28 & 39 & 938 \\
\hline
\end{tabular}

Tabel 12. Jumlah Tweet Mengenai \#prabowosandi Dari Jakarta, Bandung, Surabaya, dan Medan

\begin{tabular}{|c|c|c|c|c|c|}
\hline Kota & Jakarta & Bandung & Surabaya & Medan & Total \\
\hline Tweet & 55 & 13 & 12 & 0 & 80 \\
\hline
\end{tabular}

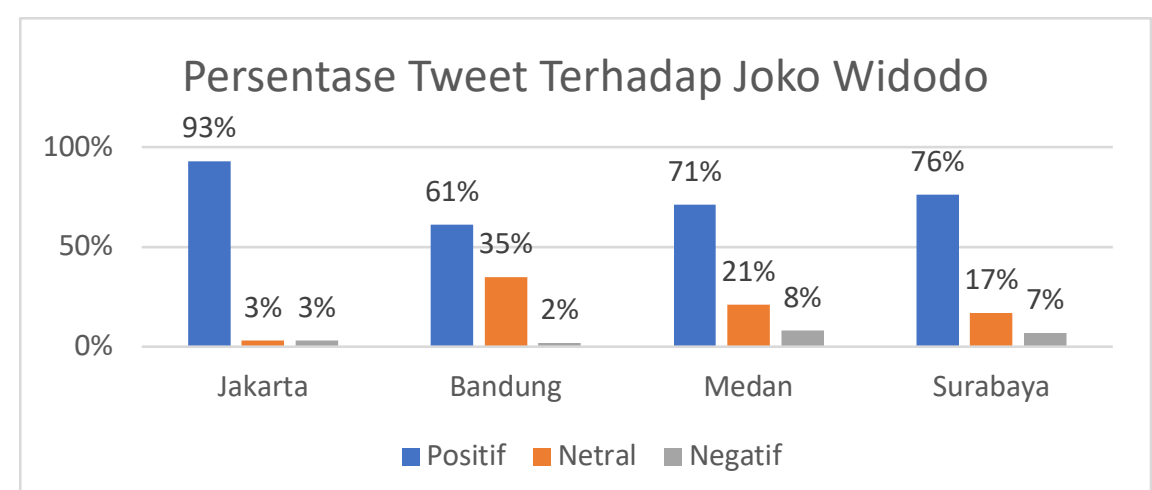

Gambar 4 Persentase Jumlah Tweet Mengenai \#jokowi2periode Dari Jakarta, Bandung, Medan, dan Surabaya 
Analisis Sentimen Pemilihan Presiden Indonesia Tahun 2019 Di Twitter Berdasarkan Geolocation Menggunakan Metode Naïve Bayesian Classification

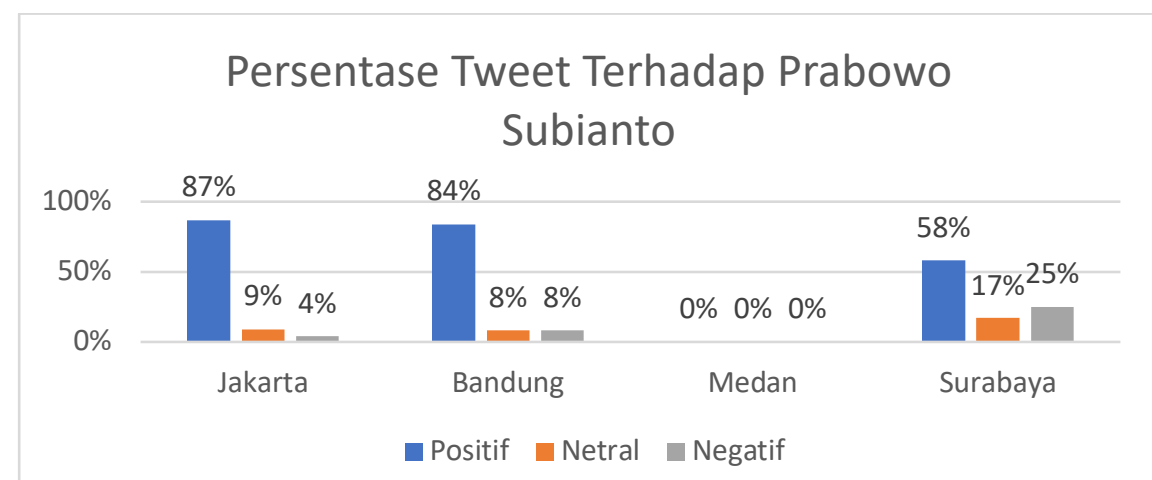

Gambar 5 Persentase Jumlah Tweet Mengenai \#prabowosandi Dari Jakarta, Bandung, Medan, dan Surabaya

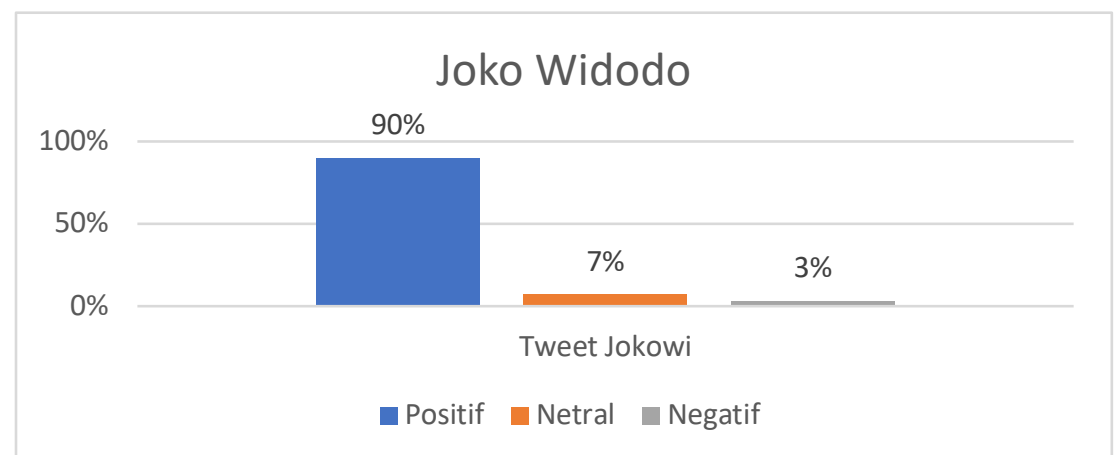

Gambar 6 Persentase Jumlah Seluruh Tweet Mengenai \#jokowi2periode Dari Jakarta, Bandung, Medan, dan Surabaya

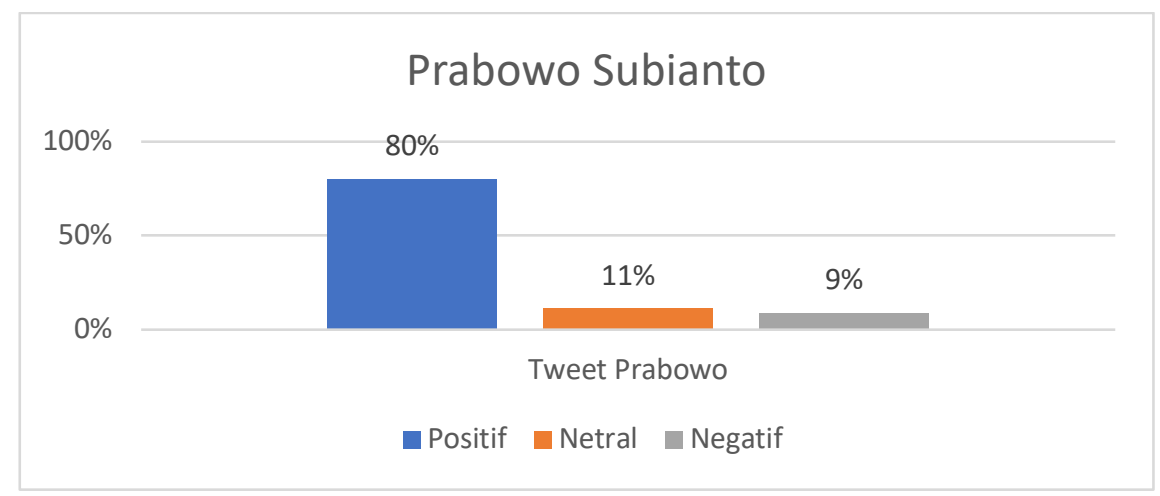
Surabaya

Gambar 7 Persentase Jumlah Seluruh Tweet Mengenai \#prabowosandi Dari Jakarta, Bandung, Medan, dan

\section{Metode Pembanding}

Pada penelitian ini, peneliti membuat metode pembanding sebagai acuan yang lebih akurat mengapa harus memakai metode Naïve Bayes. Ada pun metode pembanding yang peneliti tetapkan adalah metode Tree.J48. Hasil dari perbandingan ini dapat dilihat dari tingkat akurasi yang dihasilkan. Ada pun hasil akurasi dapat dilihat pada Gambar 8. 


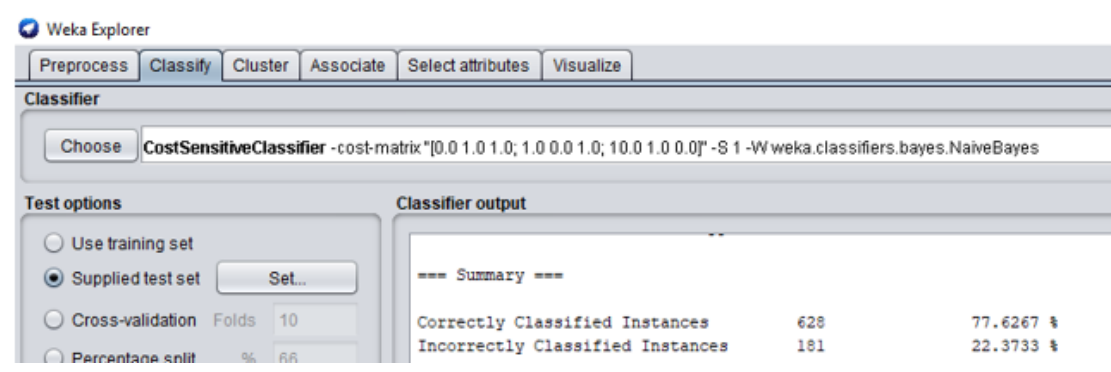

Gambar 8 Hasil Pengujian Data Training Dengan Metode Naïve Bayes.

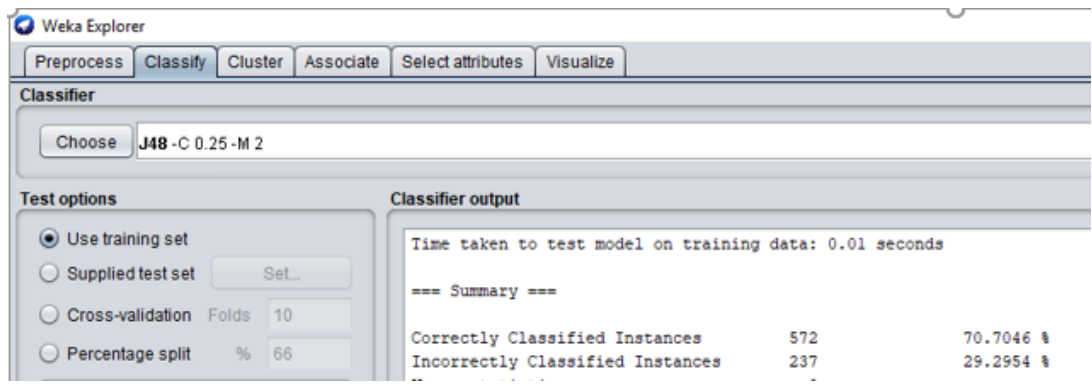

Gambar 9 Hasil Pengujian Data Training Dengan Metode Tree.J48.

Dari hasil akurasi kedua metode pada Gambar 8 dan Gambar 9 dapat disimpulkan tingkat akurasi yang paling tinggi terdapat pada metode Naïve Bayes dengan persentase sebesar 77,62\% sedangkan Tree.J48 sebesar 70,70\%. Oleh karena itu peneliti menggunakan metode Naïve Bayes sebagai metode klasifikasi data pada penelitian ini.

\section{Kesimpulan}

Konfigurasi algoritma Naïve Bayesian Classifier terhadap pra-pemilihan presiden tahun 2019 dimulai dari pengumpulan data manual melalui Twitter. Lalu dilakukannya pre-processing tehadap data sampai diklasifikasikannya pada aplikasi weka dengan perhitungan Naïve Bayesian Classifier terhadap probabilitas kata. Dengan memperoleh hasil probabilitas tertinggi, sehingga dapat mengategorikan sebuah kalimat menjadi sebuah sentimen yang sebenarnya.

Perolehan sentimen tweet berdasarkan wilayah didapat melalui titik koordinat geografis bumi yang terhubung pada aplikasi Twitter melalui API Geolocation yang terdiri dari garis lintang dan garis bujur pada google maps yang telah ditetapkan oleh pengguna.

Perbandingan klasifikasi algoritma Naïve Bayesian Classifier dengan algoritma Tree.J48 memiliki tingkat akurasi yang cukup berbeda. Di mana klasifikasi algoritma Naive Bayesian Classifier lebih tinggi dengan tingkat akurasi 77,62\% dibandingkan dengan algoritma Tree.J48 yang hanya $70 \%$.

\section{Saran}

Penulis menyarankan pengembangan penelitian lebih lanjut ialah melakukan analisis sebuah daerah secara otomatis melalui sentimen yang ada. Dengan kemungkinan pengambilan sumber data dari beberapa alternatif media sosial lainnya. 


\section{Referensi}

[1] G. A. Buntoro, A. E. Permanasari, and T. Bharata, "Sentimen Analysis Candidates of Indonesian Presiden 2014 with Five Class Attribute," Int. J. Comput. Appl., vol. 136, pp. 23-29, 2016.

[2] S. Mujilahwati, "Pre-Processing Text Mining Pada Data Twitter," Semin. Nas. Teknol. Inf. Dan Komun. 2016, pp. 49-56, 2016.

[3] A. F. Hidayatullah and A. Azhari, "Analisis Sentimen dan Klasifikasi Kategori terhadap Tokoh Publik pada Twitter," Semin. Nas. Inform. 2014, pp. 115-122, 2014.

[4] R. McCue, A Comparison of the Accuracy of Support Vector Machine and Naive Bayes Algorithms In Spam Classification. Santa Cruz: University of California, 2009.

[5] I. Sunni and D. H. Widyantoro, "Analisis Sentimen dan Ekstraksi Topik Penentu Sentimen pada Opini Terhadap Tokoh Publik," J. Sarj. Inst. Teknol. Bdg. Bid. Tek. Elektro Dan Inform., vol. 1, no. 2, pp. 200206, Jul. 2012.

[6] J. Ling, T. B. Oka, and I. P. E. N. Kencana, "ANALISIS SENTIMEN MENGGUNAKAN METODE NAÏVE BAYES CLASSIFIER DENGAN SELEKSI FITUR CHI SQUARE," E-J. Mat., vol. 3, pp. 92-99, Aug. 2014.

[7] R. A. Simanjuntak, D. Gunawan, and Amalia, "Analisis Sentimen pada Layanan Gojek Indonesia Menggunakan Multinomial Naive Bayes," Universitas Sumatera Utara, Sumatera, Indonesia, 2018. 